\title{
In Vivo Lymphocyte Activation and Apoptosis by Lectins of the Diocleinae Subtribe
}

\author{
Theolis Barbosa, Sérgio Arruda, Benildo Cavada*, Thalles Barbosa \\ Grangeiro*, Luiz Antônio Rodrigues de Freitas, Manoel Barral-Netto/ ${ }^{+}$
}

Centro de Pesquisas Gonçalo Moniz-Fiocruz, Rua Valdemar Falcão 121, 40295-001 Salvador, BA, Brasil *Centro de Ciências, Universidade Federal do Ceará, Fortaleza, CE, Brasil

This paper reports the overall effects of three lectins, extracted from Canavalia brasiliensis, Dioclea violacea, and $\mathrm{D}$. grandiflora, on BALB/c mice popliteal draining lymph nodes. These lectins have presented high stimulatory capacity on lymph node T cells. Additionally, they were able to induce apoptosis and inflammation (frequently associated with high endothelial venule necrosis). The data presented here suggest that the Diocleinae lectins studied can stimulate in vivo T cell activation and apoptosis, as well as present important side effects.

Key words: adjuvants - apoptosis - Diocleinae - lectin

In the present work we studied the in vivo stimulatory capacity of three lectins isolated by our group (Moreira et al. 1983, 1996, Moreira \& Cavada 1984, Ainouz et al. 1987), extracted from Brazilian legume species of the Diocleinae subtribe: Canavalia brasiliensis (ConBr), Dioclea grandiflora (DGL) and $D$. violacea (DVioL). These lectins have previously been shown to induce proliferation and interferon-gamma production by peripheral blood mononuclear cells in culture (Barral-Netto et al. 1992). Moreover, they presented a higher stimulatory capacity than concanavalin A (ConA), in spite of having over $80 \%$ homology with this lectin (Moreira et al. 1983, Barcellos et al. 1993, Cavada et al. 1993). We have evaluated their effects on BALB/c mice popliteal draining lymph nodes after subcutaneous injection of footpads. Lectin stimulation was found to be associated to apoptosis induction. Other effects observed included inflammation and high endothelial venule necrosis.

\section{MATERIALS AND METHODS}

Lectin-treatment of mice - The methods for lectin purification were published elsewhere (Moreira et al. 1983, 1996, Moreira \& Cavada 1984). Lec-

\footnotetext{
This work was supported by PADCT (grant number PADCT02-5BIO-01/97-02/01-47). TB and SA received fellowships from Brazilian National Research Council (CNPq). BC, TBG, LARF and MB-N are senior investigators from $\mathrm{CNPq}$.

${ }^{+}$Corresponding author. Fax: +55-71-356.2593. E-mail: mbarral@cpqgm.fiocruz.br

Received 24 October 2000

Accepted 18 January 2001
}

tin preparations were tested to exclude LPS contamination (data not shown). Inbred BALB/c mice of both sexes, 8-14 weeks of age, were used in all experiments. Animals were injected s.c. with 50 $\mu \mathrm{g}$ of lectin or bovine serum albumin (BSA, Sigma, St. Louis, MO) in $20 \mu \mathrm{l}$ of phosphate-buffered saline in the left hind footpad. As controls, the right hind footpads were injected with $20 \mu$ of PBS. As a lectin inhibition control, a ConBr solution with the lectin concentration mentioned above was prepared in phosphate-buffered alpha-methyl mannoside ( $\alpha$-MM, Sigma) $1 \mathrm{M}$, left for $1 \mathrm{~h}$ at room temperature and administered in the left footpad of eight animals, with $\alpha$-MM 1 M in the right footpads for comparison. Animals were sacrificed 15 $\mathrm{h}$ after lectin injection.

In vitro proliferation assays - Single cell suspensions in PBS were obtained from the popliteal draining lymph nodes of the mice and counted in a hemocytometer. For spontaneous proliferation assessment, lymph node cells were cultivated in RPMI medium (GibcoBRL, Rockville, MD) supplemented with $10 \%$ fetal calf serum (Sigma), penicillin, streptomycin $(100 \mathrm{U} / \mathrm{ml}$ and $100 \mathrm{mg} /$ $\mathrm{ml}$, respectively; GibcoBRL), and 2-mercaptoethanol (50 $\mu \mathrm{M}$; Sigma) for $24 \mathrm{~h}$ in 96 -well flat bottom plates (Corning, NY) in humidified atmosphere $\left(37^{\circ} \mathrm{C}, 5 \% \mathrm{CO}_{2}\right) \cdot\left[\mathrm{H}^{3}\right]$-thymidine (Amersham, UK) was added at $1 \mu \mathrm{Ci}$ per well and $\left[\mathrm{H}^{3}\right]$-thymidine incorporation was evaluated in triplicate by liquid scintillation radioactivity counting ( $\beta$-Counter 1409 DSA; Wallac, Gaithersburg, MD).

$I L-2$ receptor $(I L-2 R)$ expression evaluation One million lymph node cells were stained with anti-CD25 (IL-2R) FITC conjugated monoclonal antibody (AMT-13 clone, Sigma) in PBS with 1\% bovine serum albumin (BSA) and $0.1 \%$ sodium 
azide (Sigma). Controls included isotype control stained (Pharmingen, San Diego, CA) and unstained samples evaluated in triplicate. Flow cytometry analyses were carried out in a FACSort flow cytometer (Becton-Dickinson Immunocytometry Systems, Franklin Lakes, NJ).

Morphological evaluation of treated lymph nodes - Popliteal draining lymph nodes from lectin injected mice were fixed in $10 \%$ buffered formaldehyde (Sigma) for at least $12 \mathrm{~h}$, embedded in paraffin and stained with hematoxylin and eosin (Sigma).

Electron microscopy - Small fragments from the draining lymph nodes were immediately fixed in $2 \%$ glutaraldehyde (Sigma) in $0.1 \mathrm{M}$ cacodylate buffer (Sigma) for 1-2 $\mathrm{h}$, postfixed in osmium tetroxide (Sigma), washed in buffer, dehydrated in graded acetone and embedded in epon resin. Semi-thin sections were cut on a Reichert-Jung Ultracut E microtome with glass knives, mounted on glass slides and stained with methylene blueazurII to identify areas of lymphocyte apoptosis. Ultra-thin sections were cut with a diamond knife, mounted on copper grids and contrasted with uranyl acetate and lead citrate. Observations were carried out on a Zeiss (Germany) EM-109 electron microscope at $50 \mathrm{kV}$.

In situ evaluation of PCNA expression - The PCNA (Proliferating Cell Nuclear Antigen)-positive proliferating cells were visualized by immunofluorescence in 3-5 mm frozen lymph node sections permeabilized with saponin (Sigma) $0.1 \%$ in PBS, using anti-PCNA FITC-conjugated antibody (clone 19F4, Coulter, Fullerton, CA). The sections were photographed at the epifluorescence microscope (Axioskop; Zeiss, Germany).

In situ detection of apoptotic cells through the TUNEL assay - Apoptosis occurrence in the lymph nodes was demonstrated in 3-5 mm thick paraffin sections through the TUNEL (Terminal dinucleotidil-transferase Nick-End Labeling) technique, using the Apoptag Plus kit (Oncor, Gaithersburg, MD).

Statistical analyses - Data obtained from lymph node cell counts were compared using parametric one-way ANOVA followed by Student-NewmanKeuls Multiple Comparison Test and Student's t test. Proliferation assessment assays and flow cytometric IL-2R expression evaluations were compared through Kruskal-Wallis one-way ANOVA followed by Dunn's post test. We have used the GraphPad Prism software (v. 2.00, GraphPad Software Inc., San Diego, CA).

\section{RESULTS}

Lectins ( $50 \mu \mathrm{g} /$ footpad) promoted a remarkable enlargement of BALB/c mice popliteal lymph nodes $15 \mathrm{~h}$ after the subcutaneous injection into the footpads of mice. This augmentation was due to the expansion of paracortical and interfollicular regions (data not shown), and was accompanied by an increase in lymph node total cell counts, as expressed in Fig. 1. The number of cells in stimulated lymph nodes was significantly higher than in saline-injected controls, but no significant differences were found among the lectins studied $(\mathrm{p}=0.3430)$. Administration of bovine serum albumin (BSA), an unrelated protein, to murine footpads did not produce a significant increase in lymph node cell counts, as compared to saline injection $(\mathrm{p}=0.2896)$, and such counts were significantly lower then those obtained for lectin-stimulated nodes $(\mathrm{p}<0.002)$. Pre-blockage of $\mathrm{ConBr}$ with $\alpha$ $\mathrm{MM}$ has significantly inhibited lectin stimulatory activity (p<0.01, Fig. 1 insert). Pre-blocked ConBr stimulated lymph nodes were not significantly different from $\alpha$-MM-treated ones or PBS controls $(\mathrm{p}>0.05)$.

Upon lectin stimulation T cell areas (parafollicular, interfollicular and subcapular regions) were predominantly expanded, exhibiting abundant lymphoblasts and dividing cells. In contrast, the follicles maintained the unstimulated appearance, with small cells and lack of germinative centers (data not shown). The in situ evaluation of PCNA (proliferating cell nuclear antigen) expression reveals abundance of cells undergoing proliferation in the stimulated lymph nodes, especially in $\mathrm{T}$ cell areas (Fig. 2A). In contrast, PBS-treated control lymph nodes rarely yielded PCNA-positive cells, and in those rare cases PCNA-positive cells were seen in medullar areas (data not shown). Finally, ConBr, DGL and DVioL were found to increase the ex vivo expression of CD25 on the surface of stimulated lymph node cells (Fig. 3). CD25 comprises the a

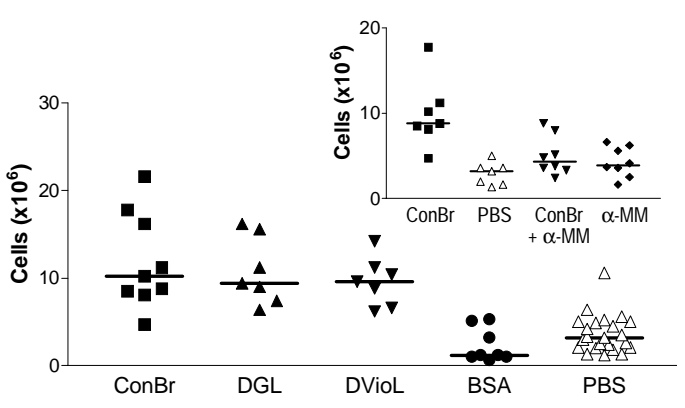

Fig. 1: cell numbers at in vivo lectin-treated popliteal lymph nodes $15 \mathrm{~h}$ after injection in mice footpads, as compared with controls PBS (phosphate-buffered saline), BSA (bovine serum albumin), and $\alpha$-MM (alpha-methyl mannoside) preblocked ConBr. Horizontal bars indicate the median of each group. ConBr: Canavalia brasiliensis lectin; DGL: Dioclea grandiflora lectin; DVioL: D. violacea lectin 
A

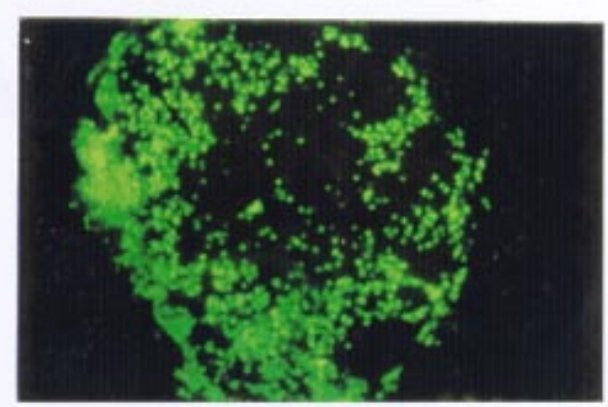

C

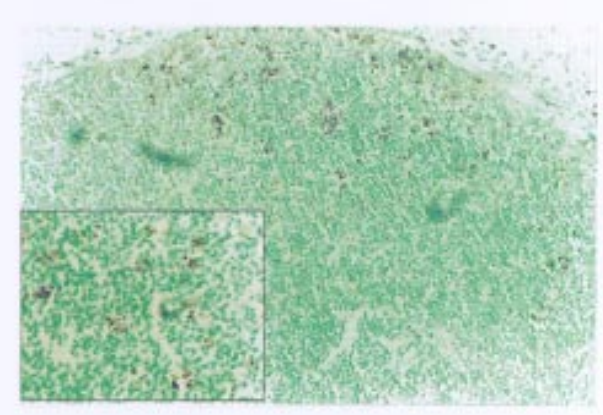

B

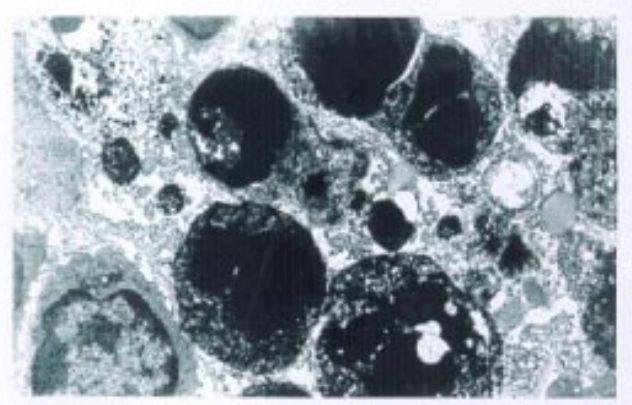

D

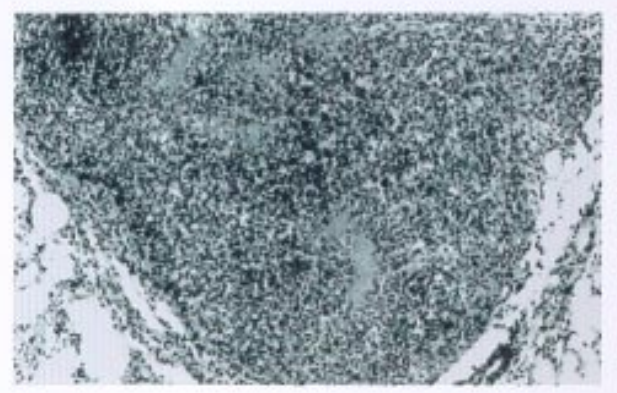

Fig. 2: lectin-induced cell activation and apoptosis in BALB/c lymph nodes. A: Canavalia brasiliensis lectin-stimulated lymph node showing numerous proliferating cell nuclear antigen-positive proliferating cells in the paracortical and subcapsular regions; B: typical morphology of apoptosis foci visualized by electron microscopy; C: apoptosis occurrence in Dioclea grandiflora lectin-stimulated popliteal draining lymph nodes. DAB-positivity indicates the presence of DNA double-strand breaks in the apoptotic cells (Terminal dinucleotidil-transferase Nick-End Labeling assay); D: D. violacea lectin-stimulated lymph node showing necrosis of high endothelial venules and massive influx of inflammatory cells to the paracortical areas.

chain of the IL-2 receptor, and its expression has also been demonstrated to be up-regulated in $\mathrm{T}$ lymphocytes upon stimulation with ConA (Black et al. 1988). Cultivation in medium for $24 \mathrm{~h}$ in the absence of in vitro stimulus (Fig. 4) demonstrated that cells in stimulated lymph nodes have increased proliferative capacity, as compared to controls

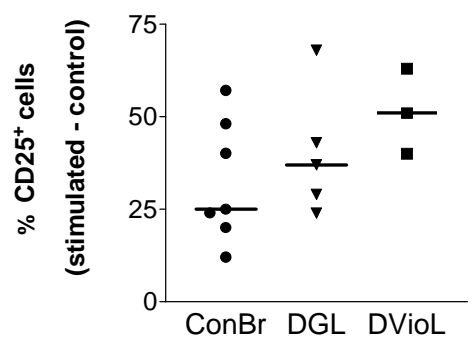

Fig. 3: interleukin-2 receptor (CD25) relative expression $15 \mathrm{~h}$ after lectin administration. Each point represents the difference between the percentage of CD25 positive cells in the stimulated and in the control lymph node of the same animal. Horizontal bars indicate the median of each group. ConBr: Canavalia brasiliensis lectin; DGL: Dioclea grandiflora lectin; DVioL: D. violacea lectin
( $p<0.0001)$. In both evaluations, no significant differences could be found among the lectins studied $(\mathrm{p}=0.2619)$.

Apoptotic foci were present in ConBr, DGL and DVioL treated lymph nodes, with typical morphology by electron microscopy (Fig. 2B). The TUNEL assay was performed to allow a better assessment of the amount and overall distribution of the apoptotic foci observed. Stimulated lymph nodes presented many positive foci (Fig. 2C), whereas controls were completely negative (data not

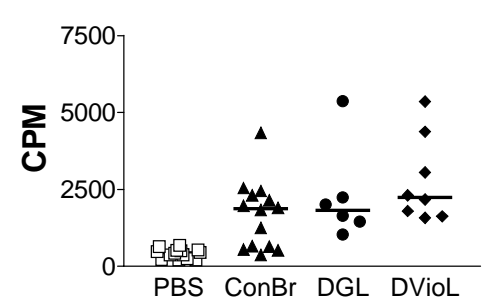

Fig. 4: in vitro spontaneous proliferation of lymph node cells after in vivo lectin treatment. Horizontal bars indicate the median of each group. CPM: counts per minute; PBS: phosphatebuffered saline; ConBr: Canavalia brasiliensis lectin; DGL: Dioclea grandiflora lectin; DVioL: D. violacea lectin 
shown). The positive foci in the stimulated lymph nodes had the morphologic features typical of apoptosis. They were located in the parafollicular, interfollicular and subcapsular regions, and were seldom present in medullar areas.

Focal inflammatory reactions with abundant macrophages and neutrophils were seen in the $T$ lymphocyte areas of the stimulated lymph nodes, especially in DGL and DVioL stimulated lymph nodes (Fig. 2D, and data not shown). Control lymph nodes rarely presented very discrete inflammatory infiltrates (data not shown). Hemorrhagic lymph nodes with associated fibrinoid necrosis of high endothelial venules were frequently observed after stimulation with $D$. violacea lectin (Fig. 2D). These features were never present in controls or $\mathrm{ConBr}$ stimulated nodes and were infrequent in DGL stimulated ones (data not shown).

\section{DISCUSSION}

The present work demonstrates that the lectins studied are able to stimulate in vivo the cells of $\mathrm{BALB} / \mathrm{c}$ mice popliteal draining lymph nodes. This stimulation is accompanied by the occurrence of apoptosis, inflammation and in some cases necrosis of high endothelial venules. The results presented here also stress the need for investigating possible side effects of lectins with therapeutic possibilities.

Lymph node enlargement and increased lymph node cell counts were observed upon lectin treatment, features that had previously been demonstrated following ConA and $\mathrm{ConBr}$ administration (Bento et al. 1993). Rodriguez et al. (1992) have reported local increases of mononuclear and polymorphonuclear cells after intra-peritoneal administration of ConA, ConBr and DGL in BALB/c mice, a phenomenon that they have attributed to lectin-

CONA ADTIVAVELDTYPNTDIGDPSYPHIGIDIKSVRSKKTAKWNMQNG

ConBr ADTIVAVELDTYPNTDIGDPSYPHIGIDIKSVRSKKTAKWNMQNG

DGL ADTIVAVELDSYPNTDIGDPNYPHIGIDIKSIRSKSTARWNMQTG

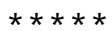

46

CONA KVGTAHIIYNSVDKRLSAVVSYPNADSATVSYDVDLDNVLPEWVR

ConBr KVGTAHIIYNSVGKRLSAVVSYPNGDSATVSYDVDLDNVLPEWVR

DGL KVGTVHISYNSVAKRLSAVVSYSGSSSTTVSYDVDLNNVLPEWVR

91

CONA VGLSASTGLYKETNTILSWSFTSKLKSNSTHETNALHFMFNQFSK

COnBr VGLSASTGLYKETNTILSWSFTSKLKSNSTHETNALHFMFNQFSK

DGL VGLSATTGLYKETNTILSWSFTSKLKTNSIADANSLHFSFNQFSQ

$\star \star$

$136 \quad 180$

CONA DQKDLILQGDATTGTDGNLELTRVSSNGSPQGSSVGRALFYAPVH

ConBr DQKDLILQGDATTGTEGNLRLTRVSSNGSPQGSSVGRALFYAPVH

DGL NPKDLILQGDAFTDSDGNLELTKVSSSGDPQGNSVGRALFYAPVH

CONA IWESSAVVASFEATFTFLIKSPDSHPADGIAFFISNIDSSIPSGS

CONBr IWESSAVVASFEATFTFLIKSPDSHPADGIAFFISNIDSSIPSGS

DGL IWESSAVVASEDATFIFLIKSPDHEPADGITFFIANTDTSIPSGS

$\begin{array}{lc} & 226 \\ \text { ConA } & \text { TGRLLGLFPDAN } \\ \text { ConBr } & \text { TGRLLGLFPDAN } \\ \text { DGL } & \text { GGRLLGLFPDAN } \\ & \star\end{array}$

Fig. 5: amino acid sequences of concanavalin A (ConA)(Naismith \& Field 1996), Canavalia brasiliensis lectin (Grangeiro et al. 1997) and Dioclea grandiflora lectin (Rozwarski et al. 1998). The asterisks indicate conserved contact residues $(12-16,99,100$, 208 and 228) of the lectins with the core trimannoside of asparagine-linked carbohydrates. ConBr: C. brasiliensis lectin; DGL: D. grandiflora lectin 
induced cellular influx to the site of injection. In our study, the cells in stimulated lymph nodes presented increased IL-2R surface expression and also high proliferation capacity. Abundant lymphoblasts and cells undergoing mitosis, assessed as positivity for PCNA, a cyclin that participates in DNA replication and is present in high amounts from $\mathrm{S}$ phase until late G2 (Celis et al. 1988), were seen only in $\mathrm{T}$-cell dependent areas. These findings suggest that during the time period evaluated, the lectins tested were able to stimulate $\mathrm{T}$ but not $\mathrm{B}$ lymphocytes, and that local activation of $\mathrm{T}$ cells probably plays an important role on the observed increases of cell numbers in the draining nodes.

The lectins studied were also able of inducing apoptosis in the T-cell dependent areas of stimulated lymph nodes. Lectin-induced $\mathrm{T}$ cell activation has been frequently associated with apoptosis occurrence (Kabelitz et al. 1994). Apoptotic cell death can result from the synthesis of potent oxidizing agents, namely nitric oxide (NO), by $\mathrm{T}$ cell activated macrophages (Mills 1991, Denham \& Rowland 1992). We have previously shown NO production by macrophages induced in vivo upon the intraperitoneal administration of the lectins from C. brasiliensis and D. grandiflora (Andrade et al. 1999).

Focal inflammatory reactions were seen in the T lymphocyte areas of the stimulated lymph nodes, especially upon DGL and DVioL administration. The s.c. administration of $50 \mu \mathrm{g}$ of lectin in the footpads produced hemorrhagic lymph nodes with associated fibrinoid necrosis of high endothelial venules after stimulation with $D$. violacea lectin, but rarely in DGL stimulated lymph nodes and never in ConBr stimulated ones. Lima et al. (1993) have previously reported strong inflammatory response and leukocyte influx to the site of injection upon subcutaneous administration of high doses of DGL, involving venule necrosis and hemorrhagic appearance. The reaction, similar to the effects of immune complex deposition, may have the participation of TNF- $\alpha$, which has been shown to be produced upon in vitro lectin stimulation (Hajto et al. 1990, Amore et al. 1993, Ribereau-Gayon et al. 1997).

The three lectins used in this work $(\mathrm{ConBr}$, DGL and DVioL) have the same nominal monosaccharide specificity for Man and Glc residues, but much higher affinities for the branched chain trimannoside, 3,6-di-O-( $\alpha$-D-mannopyranosyl)-Dmannose (Dam et al. 1998), which is found in the core region of all asparagine-linked carbohydrates. Furthermore, the lectins essentially recognize the same set of binding epitopes on the structure of the trimannoside. The $\mathrm{x}$-ray crystal structures of ConA (Naismith \& Field 1996) and DGL
(Rozwarski et al. 1998) in complex with the core trimannoside show conserved contact residues for both proteins. The x-ray crystal structure of $\mathrm{ConBr}$ in complex with the core trimannoside is not yet determined; however, the alignment of its primary structure with those of ConA and DGL shows that $\mathrm{ConBr}$ also has these same contact residues (Fig. 5). Although the complete primary sequence of DVioL is not known, its $\mathrm{N}$-terminal sequence is highly homologous with those above (Calvete et al. 1999), and residues 12-16 that directly bind to the core trimannoside are conserved. However, the differences observed in the intensity of inflammation and associated necrosis suggest subtle variations in the biological activity of these Diocleinae lectins, in spite of their high homology.

What characteristics could then account for a differential behavior for the lectins studied? These lectins differ in their binding specificities for complex type carbohydrates (Gupta et al. 1996, Dam et al. 1998). In addition, they show distinct $\mathrm{pH}$ dependent dimer-tetramer equilibrium (Grangeiro et al. 1997, Calvete et al. 1999). Only the tetravalent form is able to cause cross-linking of receptors on the cell membrane, thereby triggering the activating signal transduction pathways. Therefore, the differences in the intensity of inflammation and associated necrosis induced by ConBr, DGL and DVioL can result from small changes of key amino acid residues along the primary structure of the lectins, which affect both the affinity for complex carbohydrate and the ratio between divalent and tetravalent species.

\section{ACKNOWLEDGEMENTS}

To Dr Johan Van Weyenbergh and Dr Tânia Correia for helpful suggestions, and to Mr Jorge Tolentino, Mrs Maria Lúcia Vieira and Mrs Cristina dos Santos Mota for technical assistance.

\section{REFERENCES}

Ainouz IL, Moreira RA, Campos FAP, Richardson M, Begbie R, Stewart JC, Watt WB, Pusztai A 1987. The isolation and amino acid sequence of the beta and gama subunits of the lectin from seeds of Dioclea Grandiflora. Phytochemistry 26: 1435-1440.

Amore A, Cavallo F, Bocchietto E, Bussolino F, Gianoglio B, Peruzzi L, Porcellini MG, Coppo R 1993. Cytokine mRNA expression by cultured rat mesangial cells after contact with environmental lectins. Kidney Int Suppl 39: S41-46.

Andrade JL, Arruda S, Barbosa T, Paim L, Ramos MV, Cavada BS, Barral-Netto M 1999. Lectin-induced nitric oxide production. Cell Immunol 194: 98-102.

Barcellos GBS, Almeida LM, Moreira RA, Cavada BS, Oliveira JTA, Carlini CR 1993. Canatoxin-, concanavalin A- and canavalin-cross-reactive materials during maturation of Canavalia brasiliensis (Mart.) seeds. Planta 189: 397-402. 
Barral-Netto M, Santos SB, Barral A, Moreira LI, Santos CF, Moreira RA, Oliveira JT, Cavada BS 1992. Human lymphocyte stimulation by legume lectins from the Diocleae tribe. Immunol Invest 21: 297 303.

Bento CA, Cavada BS, Oliveira JT, Moreira RA, BarjaFidalgo C 1993. Rat paw edema and leukocyte immigration induced by plant lectins. Agents Actions 38: 48-54.

Black CD, Kroczek RA, Barbet J, Weinstein JN, Shevach EM 1988. Induction of IL-2 receptor expression in vivo: response to concanavalin A. Cell Immunol 111: 420-432.

Calvete JJ, Thole HH, Raida M, Urbanke C, Romero A, Grangeiro TB, Ramos MV, Almeida da Rocha IM, Guimaraes FN, Cavada BS 1999. Molecular characterization and crystallization of Diocleinae lectins. Biochim Biophys Acta 1430: 367-375.

Cavada BS, Moreira RA, Oliveira JTA, Grangeiro TB 1993. Primary structures and functions of plant lectins. Rev Bras Fisiol Vegetal 5: 193-201.

Celis JE, Madsen P, Nielsen HV, Gesser B, Rasmussen HH, Cruger D 1988. Cyclin/PCNA is a cell cycle modulated nuclear protein with a role in DNA replication. Arch Biol Med Exp (Santiago) 21: 417-421.

Dam TK, Cavada BS, Grangeiro TB, Santos CF, de Sousa FA, Oscarson S, Brewer CF 1998. Diocleinae lectins are a group of proteins with conserved binding sites for the core trimannoside of asparaginelinked oligosaccharides and differential specificities for complex carbohydrates. J Biol Chem 273: 1208212088.

Denham S, Rowland IJ 1992. Inhibition of the reactive proliferation of lymphocytes by activated macrophages: the role of nitric oxide. Clin Exp Immunol 87: 157-162.

Grangeiro TB, Schriefer A, Calvete JJ, Raida M, Urbanke C, Barral-Netto M, Cavada BS 1997. Molecular cloning and characterization of $\mathrm{ConBr}$, the lectin of Canavalia brasiliensis seeds. Eur J Biochem 248: 43-48.

Gupta D, Oscarson S, Raju TS, Stanley P, Toone EJ, Brewer CF 1996. A comparison of the fine saccharide-binding specificity of Dioclea grandiflora lectin and concanavalin A. Eur J Biochem 242: 320326.

Hajto T, Hostanska K, Frei K, Rordorf C, Gabius HJ
1990. Increased secretion of tumor necrosis factors alpha, interleukin 1, and interleukin 6 by human mononuclear cells exposed to beta-galactoside- specific lectin from clinically applied mistletoe extract. Cancer Res 50: 3322-3326.

Kabelitz D, Oberg HH, Pohl T, Pechhold K 1994. Antigen-induced death of mature T lymphocytes: analysis by flow cytometry. Immunol Rev 142: 157-174.

Lima MS, Albuquerque DA, Ibanez OM, Sant'anna O 1993. Inflammatory cutaneous reaction induced by the lectin of Dioclea grandiflora (Mart.). Mem Inst Oswaldo Cruz 88: 599-603.

Mills CD 1991. Molecular basis of "suppressor" macrophages. Arginine metabolism via the nitric oxide synthetase pathway. J Immunol 146: 2719-2723.

Moreira RA, Barros ACH, Stewart JC, Pusztai A 1983. Isolation and characterization of a lectin from the seeds of Dioclea grandiflora (Mart.). Planta 158: 63-69.

Moreira RA, Cavada BS 1984. Lectin from Canavalia brasiliensis (Mart.). Isolation, characterization and behavior during germination. Biologia Plantarum (Praha) 26: 113-120.

Moreira RA, Cordeiro EF, Grangeiro TB, Martins JL, Ramos MV, Oliveira JTA, Cavada BS 1996. Isolation and partial characterization of a lectin from Dioclea violacea Benth seeds. Rev Bras Fisiol Vegetal 8: 23-29.

Naismith JH, Field RA 1996. Structural basis of trimannoside recognition by concanavalin A. J Biol Chem 271: 972-976.

Ribereau-Gayon G, Jung ML, Frantz M, Anton R 1997. Modulation of cytotoxicity and enhancement of cytokine release induced by Viscum album L. extracts or mistletoe lectins. Anticancer Drugs 8 (Suppl. 1): $\mathrm{S} 3-8$

Rodriguez D, Cavada BS, Abreu-de-Oliveira JT, deAzevedo-Moreira R, Russo M 1992. Differences in macrophage stimulation and leukocyte accumulation in response to intraperitoneal administration of glucose/mannose-binding plant lectins. Braz J Med Biol Res 25: 823-826.

Rozwarski DA, Swami BM, Brewer CF, Sacchettini JC 1998. Crystal structure of the lectin from Dioclea grandiflora complexed with core trimannoside of asparagine-linked carbohydrates. J Biol Chem 273: 32818-32825. 